石高添加量が $\mathrm{SO}_{3} 2.5 \%$ で，短期および長期材令を 通じて最大であった。ての結果と（3）ii）の結果と占

り, 最適石膏添加量でセメントの強サが最大となる理 由の1つは,アリットの水和速度が大ならしめられる ことであると考光られる。

(4)，(3) の水和率とXX線回折により定量したクリンカ 一中の鉣物含有量とより，セメント硬化時におけるクリ ンカ一の水和量救求めた結果，村令1日で 20 50\%, 28 日で 40 80\%程度であり，そのうちアリットの少な いクリンカーの場合を除き,アリットの水和量省最も大

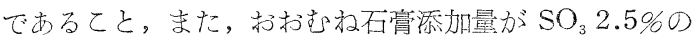
ときアリットの水和量が最も大きいととがらかがわれ，

（3） iii）の見解办沁っそう確少られた。

$$
\text { 文献 }
$$

1) R.H. Bogue, The Chemistry of Portland Cement, p 670, 1956 New York; Ind. Eng. Chem., 26, 837 (1934)

2) L. Forsén, Proc. 2 nd Intern. Symposium on Chemistry of Cement, p 298, 1938, Stockholm.

3) E.P. Flint and L.S. Wells, J. Res. NBS., 12, 751 (1934)

4) F.O. Anderegg and D.S. Hubbell, Proc. ASTM., 29, $554(1929) ; 30,572(1930)$

5）山日悟郎, 小野田研究染報, 10, 17 (1958)

6）山口悟郎外，セメント技術年報，XI，24，28（1957）； XII, 16 (1958); XIII 31 (1959)

7）山口悟郎，竹本国博，内川浩，高木茂栄，セメント技術 年報, XIII 62 (1959); 小野田研究巢報, 11, 154(1959)
8）竹本国博，内川浩，高木茂栄，窝協，68 [775]180(1960)

9) J.W. Jeffery, Proc. 3 rd Inter. Symposium on Ch. emistry of Cement, p. 41 1952, London

10) K.T. Greene, J. Res. NBS., 32, 1 (1944)

11) L.T. Brownmiller and R.H. Bogue, Am. J. Sci., 23, 501 (1932)

12）山内俊吉, 㝘協, 45, 279, 361, 433, 611, 880 (1937) 46, 66 (1938)

13) M.A. Swayze, Am. J. Sci., 244, 1, 65 (1946)

14）山口悟郎, 池上裕夫, 白須賀公平, 天野腾江，セメント 技術年報, XI，24（1957）

15) H. Insley, J. Res. NBS, 17, 353 (1936)

16) R.H. Bogue, The Chemistry of Portland Cement, 2 nd ed., p. 174, 1955, New York

17) R.H. Bogue, Ind. Eng. Chem., Anal Ed., 1, 192 (1929)

18) F. Lea and T. Parker, Build. Res. Tech. Paper, No. 16, (1935)

19) L.A. Dahl, Rock. Products, 41, 9, 48 (1938); 42, 4, 50 (1939)

20) G.W. Ward, J. Res. NBS, 26, 49 (1941)

21) L.S. Brown, Proc. Am. Concrete Inst., 44, 877 (1948)

22）山口悟郎，梶荎基彦，田中一好，セメント技術年報，XIII 31 (1959)

23) H.P. Klug and L.E. Alexander. X-ray Diffraction Procedures, p 415, 1954, New York.

24）竹本国博，高术茂栄，小野田研究荣報，11 [3] 209 (1959)

25) W. Lerch, Proc. ASTM., 46, 1252 (1946)

26）福田良治, 小野田研究彙報，6，28（1954）

27) E.F. Gonnerman, Proc. ASTM, 34, 244 (1934)

$(7 / 4 / 60$ 受付 $)$

\title{
釉と金属との界面状態の観 察
}

アルミニウム珐瑯の融着機構の研究

\section{山田敏尖 \\ (名古屋工業大学 金属工学科)}

\section{Observation of the Appearance of the Boundry Surface Bntween Enamel-Glass and Metal.}

Studies on the Mechamism of Adherence of Aluminium Enamels

By Toshio YAMADA

(Dept. of Metal Technology, Nagoya Tech. Inst., Nagoya)

\begin{abstract}
The results obtained so far by authors have proved that the anodic oxidation was the best for the pickling process of aluminium enamels, since it gave the better effects in adherence, colour and luster, than the chemical pickling or the application of the coating on untreated surface.

Having discussed in a previous paper (T. Yamada, J. Ceram. Assoc. Japan, 68, 64 (1960)) the influences of enamels on the different states of metal surface brought out by sevral pickling processes, the author made the direct observations of metal-enamel interface under metal and electron microscopes, the results of which are presented in this reports.

By the anodic oxidation of aluminium a compact and uniform film was formed, which,
\end{abstract}


on the trials changing the time of firing, has proved that the intermediate layer formed by the diffusion of coating into the oxide film is doing much toward the stronger adherence of enamels.

On the contraly, the oxide film formed by a chemical process was rough and uneven containing many cracks. Owing to such structure, the enamel would rapidly worn out, and the enamel would penetrate through the cracks comming into direct contact with metal surface. In such cases it is very liable to get the black coating which easily falls off from the base. Chemical processes make the adherence poor.

The author was able to confirm that anodic oxidatiom was the best for pickling aluminium surface, in the single coating process, since it gave an uniform, compact film which guarantees always "the better adherence."

\section{正。緒言}

アルミニウム珐概はいろいろの長所を有しているが, その反面未研究の分野がはなはだ多い。その最も重袈な 問題の 1 つは,フリットと素地放との融着機構である。 これまでの著者ら゙の研究によればアアルミニウム㻉琪 用素地板の表西処理法としては，陽極酸化処理したもの が化学好理, 無処理のものに比較して密着性, 班瑯の色 及びつやなどが最も贋秀であるととがわかった・前郝2 では，各処理板の表面状態に対するフリットの影響に ついて袷討したが，本報ではフリットと金属との界面の 融着状態を電子顕微鏡および金属顕微鏡で観察した結果 を報告守る。

\section{II. 電子顕微鏡観察}

a） 試験片の作製素地板は前報 ${ }^{2)}$ と同様，大きさ $50 \times 20 \times 1 \mathrm{~mm}$ のアルミニウム $2 \mathrm{~S}$ を使用した. 素地板 の脱脂，酸洗は前報と同様で，表面処理条件は表一1に 示す.

Table 1. Conditions of anodic oxidation and chemical treatment for aluminum plate of lead enamel.

Solution Tempera- Treatment A.C Voltage used $(\%)$ ture $\left({ }^{\circ} \mathrm{C}\right)$ time (min) (V)

MBV method $\left\{\begin{array}{lll}\mathrm{Na}_{2} \mathrm{CO}_{3} & 5 \\ \mathrm{Na}_{2} \mathrm{CrO}_{4} & 1.5\end{array} \quad 90 \sim 100 \quad 3 \sim 5\right.$

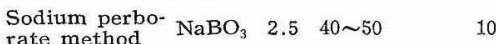

1050

Table 2. Composition of lead frit used. $\begin{array}{lllllll}\mathrm{SiO}_{2} & \mathrm{PbO} & \mathrm{B}_{2} \mathrm{O}_{3} \% & \mathrm{Na}_{2} \mathrm{O} \% & \mathrm{~K}_{2} \mathrm{O} \% & \mathrm{Li}_{2} \mathrm{O} & \mathrm{CaF}_{2} \%\end{array}$ $\begin{array}{llllllll}\begin{array}{c}\text { Lead frit } \\ \text { TP-3 }\end{array} & 30 & 30 & 15 & 8 & 5 & 8 & 4\end{array}$

フリットは表一 2 鉛系（TP-3）を使用した・前記各 処理した素地板にフリットを塗布し乾燥後, 温度 $580^{\circ} \pm$ $10^{\circ} \mathrm{C}$ の炉中に入れ，全面が一様に輝き始めた時を 0 秒 として，5，15，30，60 秒と筧付時間を変化させて，武 験片をつくった。とれらのものを埋込み樹脂でかため， 断面范エメリーペーパー ( $1 \mathrm{G}, 1 \mathrm{~F}, 0 ， 03 ， 04,05)$ で 粗磨きした後ハハフ研穈を行ったものをさらに5\%苛性 ソーダ溶液で 10〜15 秒エッチングを行ったものを電子 顕微鏡用試料とした。

b) 観察結果電子顕微鏡は日本電子光学研究所

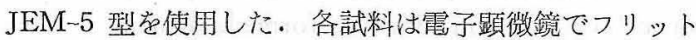

と金属の界面状態を見るために，試料面にプラスチック （アセチルセルローズ）の皮膜を作り，乙れ党械的に 剝離した後，クロムでシャドーイングを苍行ってカーボン 真空蒸着する 2 段レプリカ法を採用した・フリットと金 属との界面状態の観察結果は 写真一 1 4 亿示す. 写真

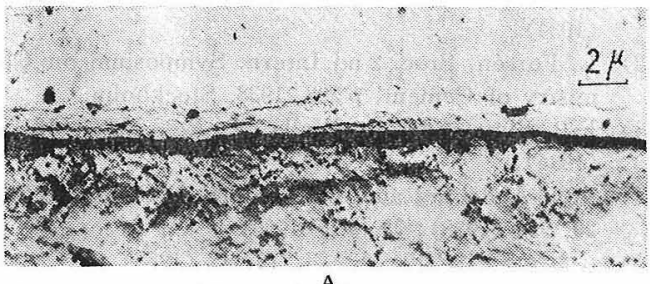

A

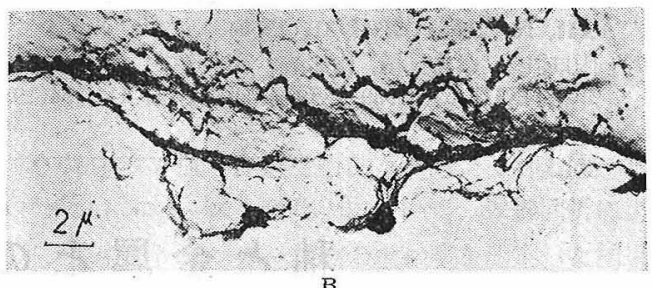

A : Treatment by anodic oxidation $\left(10\right.$ min $2.5 \% \quad \mathrm{NaBO}_{3}$ solution)

B : Treatment by MBV method

Photo 1. Electronmicrophotographs of the cross section of Al-plate subjected to anodic oxidation and chemcial treatment.

-1のAは $2.5 \%$ 過研酸ソーダ溶液で陽極酸化処理 $(\mathrm{A} \cdot \mathrm{C}$ $50 \mathrm{~V}, 10$ 分間）したものの断面で，上部は埋込み樹脂， 中間部は酸化皮膜，下部は金属である。写真一1のBは 化学処理法である MBV 法つで処理したものの断面を示 す.とれでわかるように，陽酴酸化処理による皮膜は化 学爸理法によるものより皮膜の厚さか均一，加緻密で ある. 一方化学処理法のものは皮膜の愿さが非常に不均

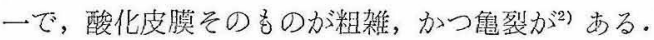

写真一2は军真一1 のAに示した陽極酸化皮膜の上に フリットを塗布し，做付時間をかえて燒付けた時のフリ ット一金属界面の状態を示す，写真一 2 の $\mathrm{A}_{5}$ は焼付時 䦓 5 秒のもので，とれはフリットと酸化皮膜とがまだ反 応しない状懸を示す。写真一2の $\mathrm{A}_{15}$ は焼付時間 15 秒

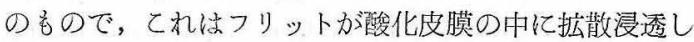
た状態を示す. $A_{30}$ は焼付時間 30 秒のもの. $A_{60}$ は焼 

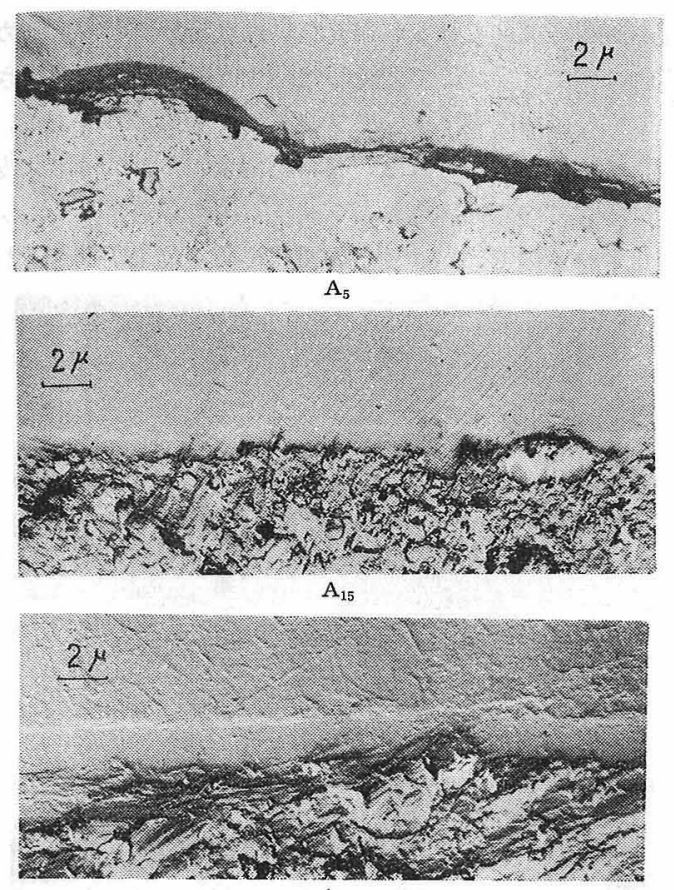

$\mathrm{A}_{30}$

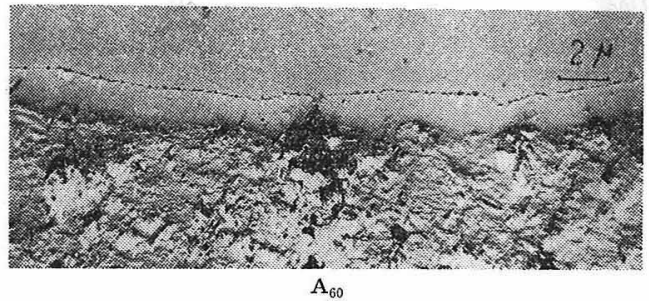

A : Treatment by anodic oxidation.

Suffixes denote the firing time in seconds.

Photo 2. Electronmicrophotographs of the cross section of aluminium enamel held for va. rious firing time. (for anodic oxidation treated Al-plate.)

付時間 60 秒で，てれはフリットと酸化皮膜間の反応が 進み，もとの酸化皮膜が消失し，界面にほぼ平行に微細 な結晶様の小粒子がー列に並んでいるのが見られる。写 真-3の $\mathrm{B}_{15}$ は写真一 1 のB に示した化学処理皮膜の 上に，フリット焼付時間 15 秒で炾付けた時のフリッ トと界面の状態学示す．前記のように化学処理法による

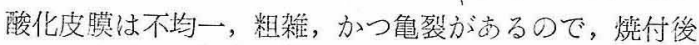
は酸化皮膜の久楩個所で，フリットが金属面と直接に接 しているととが写真によって明らかにされている，写真 -3の $\mathrm{B}_{30}$ は焼付時間 30 秒のもので，フリットが酸化 皮膜の中に拡敨して中間層を形成し，またその下部には まだフリットに接しない酸化皮膜が部分的に残存してい る状態である.写真一 4 の $\mathrm{C}_{15}$ は素地板を脱脂,酸洗した ものの上にフリット觉 15 秒椪付けたものを示す。 $C_{30}$, $\mathrm{C}_{60}$ は㜔付時間 30 秒, 60 秒のものである.とれらのも のは酸化皮膜方洊在しふいので。フリットは金属と直接 に接していることを示している。

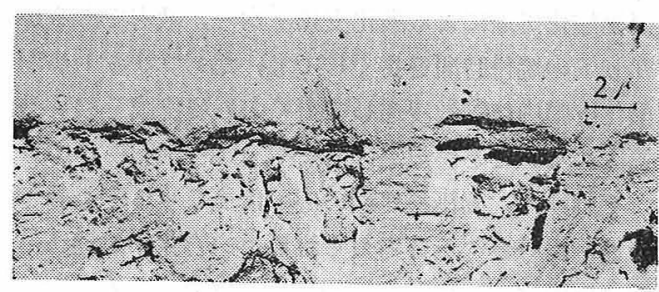

$\mathrm{B}_{15}$

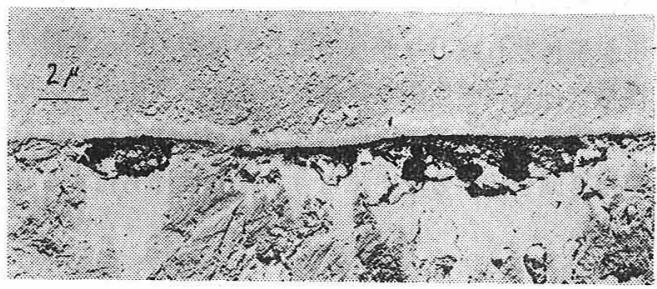

$\mathrm{B}_{30}$

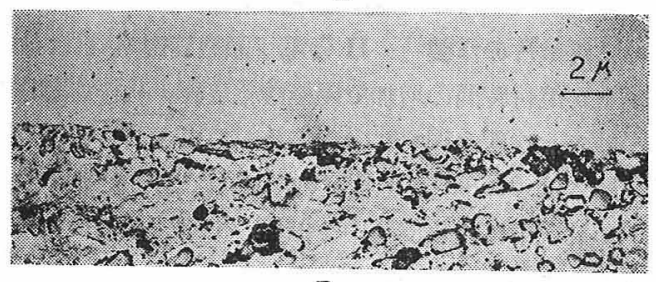

$\mathrm{B}_{60}$

B : Treatment by MBV method.

Suffixes denote the firing time in seconds.

Photo 3. Electronmicrophotographs of the cross section of aluminium enamel held for various firing time. (for chemicaly treated Al-plate.)
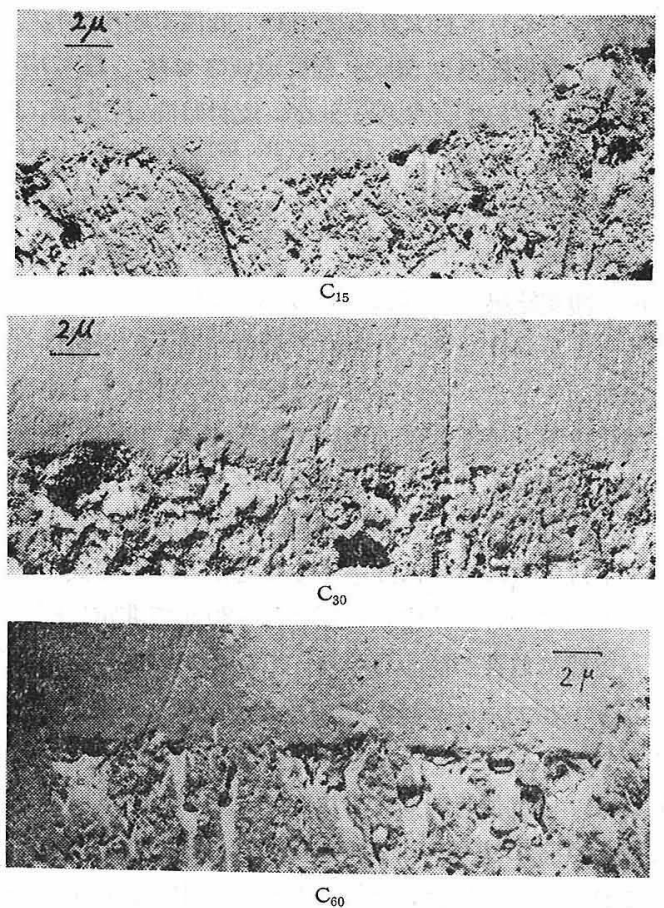

C : No treatment.Suffixes denote the firing time in seconds.

Photo 4. Electronmicroscopic-photographs of cross section of aluminium enamel held for various firing time. (for no treated Al-plate.) 
陽極酸化処理による酸化皮膜は均一，緻密であるから フリットの焼付時間を長くしても，ただフリットが均一 亿酸化皮膜中に拡散浸透して行くのみで皮膜そのものは 破壤されないととが以上の観察によって明らかにされ た.それ学，陽極酸処理のものはフリットと金属との 密着性が良好となると考光られる。一方化学処理法によ る酸化皮膜は，陽極酸化処理による皮膜よりも不均一， 粗雑，加龟裂がある。とのような酸化皮膜の上にフリ ットを焼付ければ, フリットはこの亀裂の所から浸入し て直接素地金属と反応し, またフリットと皮膜との反応 亿よって新たて生じる中間層をるはがし，フリット自体 が直接金属と接するととになり，密着性は劣化すると考 えられる。

\section{III. 金属顕微鏡観察}

a) 試験片の作製ＩI の霞子顕微鏡観察では, フ リットが暁付時間の增加で陽極酸化皮膜, 化学処理皮膜 を浸蝕する状態を調へたのであるが，ての場合の酸化皮 膜の厚さは 0.6 1.5 $\mu$ 程度の薄い層であるため, フリ ットか焼成中に酸化皮膜中を拡散して行く過程はよく観 察することができない，それ切えこの拡散過程を観察す るために特厚い酸化皮膜离形成させて, その蛙成中の

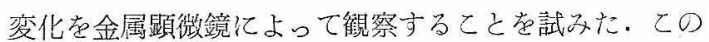
実験では, 硫酸一落酸の混合溶液 ${ }^{3)}$ (溶液組成, 硫酸 75 $\sim 150 \mathrm{~g} /(7(7 \sim 14 \%)$, 葰酸 $7.5 \sim 22.5 \mathrm{~g} / l)$, おょざ前項と 同ビアルミニウム板 $2 S$ を使用して低温で陽極酸化処理 を行い, 酸化皮膜を $100 \mu$ 程度形成させた。II の場合 と同様に，その上にフリットを，焼付時間 $1,3,5,10$, 20 分々変光て整付け，前述のように研磿したものにつ いて，金属䫒微鏡によりフリットと金属との界面状態の 観察を行った.

b) 観察結果 写真一 $5 の A_{1}$ は処理素地板に鉛系 フリットを $580^{\circ} \pm 5^{\circ} \mathrm{C} の$ 炉中で筧付時間 1 分烧付けたも のの断面である.との写真では上部がフリット，中間部

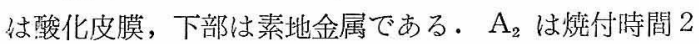
分のものであるＡ，と同椂まだフリットは皮膜に浸透 しない状態を示す。しかし焼付時間が 3 分になると, フ リットは急激に皮膜に浸透することが $\mathrm{A}_{3}$ の写真でわか る.この場合, 酸化皮膜の厚さは $120 \mu$ で非常に厚いの で, 皮膜に亀裂が認められる。との亀裂の間隙を通して フリットがアルミニウム素地と直接に接触する結果とし て，気泡を生じている状態がよくうかがわれる：写真一 5 の $A_{5}$ は缆付時間 5 分の場合で, 焼付時間 3 分の場合 よりもさらに深くフリットが皮膜に浸透している。

これらの写真では，金属の酸化皮膜中への拡散はほ んど認ぬられず，フリットがー方的に酸化皮膜中に搪散 してゆくありさまが明暸に認められる。乙の拡散は焼付 時間 3 分後においては心゙めて認められ，10 分までその
行進が䫫著に見られるが，それ以後は著しい進行は認》 られなくなる。汃くて変質した酸化度膜中間層か形成さ れる.との中間層によってフリットと金属との融着が， 強化されると考光られる。な抾地金属の拡散は酸化皮 “膜によって強く抑制され，フリット中に浸透することが 防止されるので, フリットの黑化觉防ぐ効果が期待され

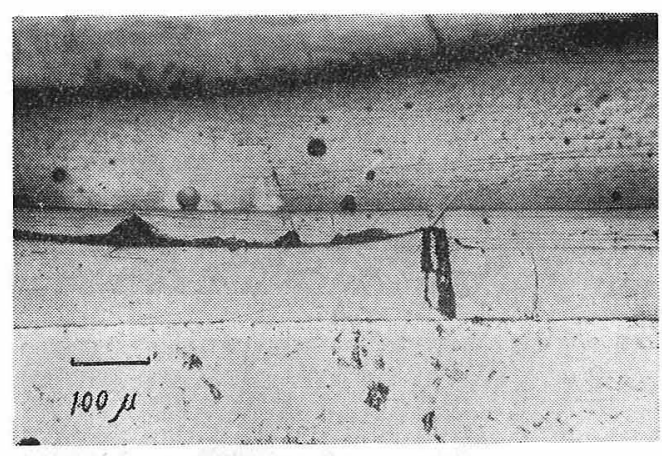

$\mathrm{A}_{1}$
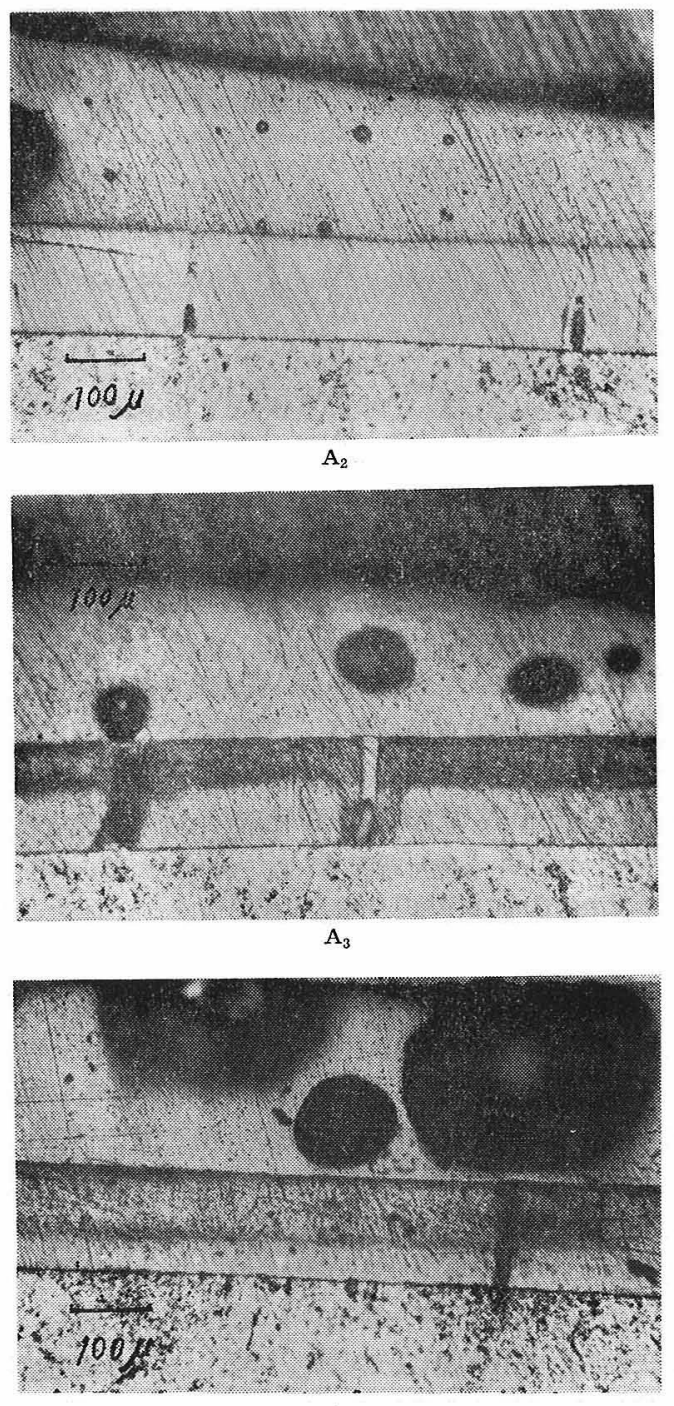

$\mathrm{A}_{5}$ 

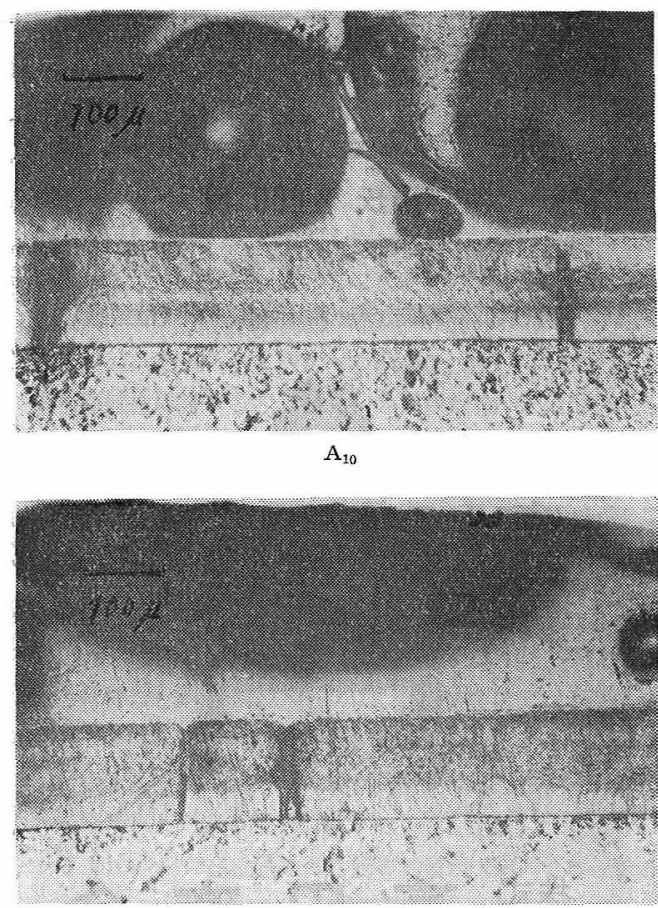

$\mathrm{A}_{20}$

A : Treatment by anodic oxidation $\left(\mathrm{H}_{2} \mathrm{SO}_{2}-\left(\mathrm{CO}_{2} \mathrm{H}\right)_{2}\right.$ solution). Suffixes denote the firing time in seconds.

Photo 5. Relation between fluxing action of oxide film used and the appearance of the cross section of aluminum enamel held for various firing times:

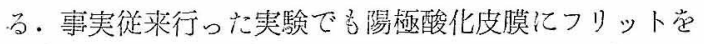
焼付けたるのは，黑化しにくいことが認められた。

\section{IV. 縕 言}

（1）晹極酸化処理による酸化被膜は維密，均一で市り
この上にフリットを焼付時閒を変えて焼付けた場合，フ リットは皮膜中に浸透し，酸化皮膜の变質した中間層が 形成される・陽極酸化処理によってフリットと金属との 密着性か強化されるのは，とのようにフリットか酸化皮 膜中に漫透するためと考学られる。

（2）化学処理法による皮膜は粗雑で盘裂があり，かつ 不均一である.この上亿フリット竞付けた場合，フリ ットは皮膜との間に中間層を形成するが，皮膜が粗雑な ためにフリットに容易に浸蝕され，かつフリットは龟裂 のところより浸入して直接素地金属と接する。このため フリットはきかめて黑化しや字い。安た生成皮膜は金属 素地よりはがれやすく，てのため㖶と素地板の密着性は 不良である。

以上の観察結果より，アルミニウム珆晲の 1 回焼付の ための綔地金属の表面処理法としては，化学処理法より き陽極酸化処理法が，フリットと金属の密着去を強化す る処理方法であると考允られる。

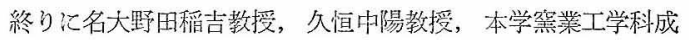
瀬省教授に御指導賜わったこと，終始御鞭㨒岂いただいている 京大田代仁教授飞感謝するものである. この研究のため財国法 人軽金属奨学会より研究費を叔くられたこと, 電子影微鏡写真 についで, 本学の学生中付善吉君ならびに工業技術院名古屋 工業技術試験所田崎㵎三技官，低温陽極睃化処理については， 新三菱重工㘹株式会社 名古屋航空機製作所鳥居正次部長附㴬 意孝表す。

(本稿况一部昭和 35 年 4 月 3 日, 日本金㾖学会春期諲演大会 発表)

\section{文献}

1）山田敏夫, 富野鎮一郎, 㷱協, 67 [1] 88 (1959)

2）山田敏夫, 窒協, 68 [6] 163 (1960)

3）雫石重成, 新三菱重工技報, 1 [2] 77 (1960)

(7/29/60 受付) 